\title{
MINUTES OF THE 1977 ANNUAL MEETING OF THE SOCIETY
}

The Annual Meeting of the Bibliographical Society of Canada - la Société bibliographique du Canada - was held at 8:00 p.m., June 9, 1977, in la Bibliothèque nationale du Québec, Montréal, Québec. About eighty-four members and guests were present.

The President, Dr. Olga Bishop, welcomed all members and guests and expressed our thanks to M. Jean-Rémi Brault, Conservateur en chef, and to la Ministère des Affaires Culturelles for inviting us to hold our meeting in this historic library. Brault then welcomed those present on behalf of his Library and his Ministry.

The President then gave the following report:

"The Council met in October and again in March in Toronto. The highlights of the meetings have been reported in the Bulletin. However, there are certain items which need a further report.

The second edition of the Bibliography of Canadian Bibliographies is now completely out of print. A committee, composed of Peter Greig and Douglas Lochhead, have been drawing up the terms of reference for a third edition. These are just about complete and will be published in the 1977 edition of the Papers. I am very happy to report that Mr. H. Pearson Gundy has consented to edit the 1977 Papers. Both the Lovell facsimile and the Index to the Canadian Monthly and National Review, prepared by Marilyn G. Flitton, have been received with great enthusiasm both by the membership and by others. The Society is greatly indebted to Mrs. Theresa Goldie Falkner for providing each member of the Society with a copy of John Godlie's Diary of a Journey through Upper Canada. . .1819.

Some of the Society's archives have now been deposited in the Archives of Queen's University. Others will be added. A notice did appear in the last issue of the Bulletin concerning the Society's archives. There are some items which I have not mentioned as they will either come up in Committee reports or later during the evening.

I would like to take this opportunity to thank all the members of Council for their work during the past year, particularly Miss Norma Freifield and Mr. T.B. Higginson, who retire from Council at the end of this meeting. Special mention and thanks are extended to Mrs. R.C. Jacobsen, our Secretary-Treasurer, whose devotion to the Society has helped us accomplish far more than we would have otherwise."

Since the minutes of the last Annual Meeting would appear in the 1976 volume of the Papers, it was moved by Miss Norma Freifield, seconded by Miss Mary Jane Henderson, that they be taken as printed. Carried. 
Under business arising from the minutes, a resolution had been received at the last meeting, urging early publication of the proceedings of the National Conference on the State of Canadian Bibliography, held in Vancouver in May 1974. The President was pleased to report that this publication was now available from Ottawa.

The Secretary-Treasurer then presented the Treasurer's report, noting a balance of $\$ 2,594.43$ in the General Account and $\$ 2,870.95$ in the B.C.B. account. She mentioned that we would have the publication costs of the 1975 and 1976 volumes of the Papers to meet in the coming year. It was moved by Mrs. Jacobsen, seconded by Miss Agnes O'Dea, that this report be adopted. Carried.

The Secretary then read the report of the Publications Committee in the absence of its Chairman, Mr. H. Pearson Gundy. It was as follows:

"I have the honour to present the following report for the year 1976-77:

Up to the present time the Society's publications, including the Bulletin and the annual Papers have been issued without subsidy from any outside sources. The annual dues and additional income from the sale of back titles have been sufficient to cover expenses. Rising printing and publication costs, however, now make it necessary to seek outside support for our publishing programme. For lack of funds, the Publications Committee has had to turn down one or two ambitious proposals, or postpone them for future consideration.

Council has endorsed as our next book publication (if a grant can be obtained to cover printing costs) a collection of "Essays in Canadian Bibliography", to be edited by our past President, Professor Douglas G. Lochhead. This volume will bring together a score of articles originally published in our Papers, in the Transactions of the Royal Society of Canada, in the volume of Background Papers of the Ontario Royal Commission on Book Publishing, and in other sources not readily accessible to the average student or researcher. As it will be a larger volume than those heretofore published, there will be a modest charge to members who wish to obtain the book (if and when it appears.)

Miss Edith Firth, because of the pressure of work, has had to resign as editor of the Papers of the Society, but reports that volumes XIV and XV will be off the press shortly. The Society is indebted to Miss Firth for the time she has taken out of her busy schedule and for the care she has given to the task of editing. Mr. Gundy has agreed to act as interim editor.

Miss Elizabeth Hulse also deserves the Society's thanks for editing the Bulletin and making it such an interesting and useful publication."

Mrs. Jacobsen moved, seconded by Miss Marion Cameron, the adoption of this report. Carried.

Mr. William F.E. Morley then presented the following report of the Committee on Bibliographical Services for Canada:

"The Committee on Bibliographical Services for Canada was established by the National Library Advisory Board in 1975, in pursuance of a resolution made at the National Conference on the State of Canadian Bibliography, held in Vancouver in 1974. In February, 1977, the National Library announced the further establish- 
ment of a permanent Secretariat for the Committee. Mr. Peter E. Greig, the Secretary, is a member of the Bibliographical Society of Canada. The membership of the Committee is composed of representatives of some nine associations, including the Bibliographical Society of Canada.

The purposes of the Committee (also known as the CBSC) are to determine bibliographical needs, to investigate and make recommendations concerning the support of bibliographical activities, to assign priorities for the support of bibliographical activities, and to assist in the coordination of bibliographical activities in Canada. Bibliography, in this context, is defined as the identification, description, and dissemination of recorded information.

The Committee attempts to meet twice a year, and to date it has met on four occasions. As this is the first report on the CBSC to our membership, I shall briefly review these meetings.

The foundation meeting was on the 21st May, 1975, at the National Library, Ottawa. The National Librarian welcomed the members assembled, and explained that the new body was to be a committee of the National Library Advisory Board. A member of that board, Ms. Margaret Williams, was appointed to chair this first meeting, concerned with framing the Committee's terms of reference. It then considered the recommendations of the Vancouver Conference, and Dr. Sylvestre's long-standing interest in the co-ordination of Canadian indexing and abstracting services.

At the second meeting held in the same place on the 3rd October, 1975, Dr. Sylvestre stressed the need for a meeting with representatives of Canadian indexing and abstracting services, and the Committee then discussed ways and means. A survey was planned, to look into the present situation and needs of these services, in preparation for the meeting.

On the 22nd-23rd of November, 1976, the CBSC held its third meeting, also in Ottawa, and the Secretary reported on the survey he had undertaken on behalf of the Committee. A two-day workshop was decided upon for March 1977. Representatives from eighteen Canadian abstracting and indexing services were invited by the National Librarian to discuss four topics, coverage, financing, and editorial and technical production in indexing and abstracting services. The Secretary prepared a detailed directory of the eighteen services, based on the survey returns, for distribution to participants in the workshop. The Committee also examined a number of reports prepared by its members on various bibliographical activities and needs in Canada, as part of a research programme organized by the Secretary of the CBSC.

The fourth and most recent meeting of the Committee on the 9th of March of this year and also in the National Library, followed immediately upon the workshop on Canadian indexing and abstracting services, held on the 7-8th March. The workshop, under the chairmanship of the ABSTI member on the CBSC, Dr. Philip Lapp, was opened by Dr. Sylvestre. Position papers were delivered on the four topics agreed upon; then the participants, as well as the members of the CBSC formed into four discussion groups. At the final plenary session each group presented its recommendations. At the CBSC meeting the following day, these recommendations were revised for submission to the National Library Advisory Board and other bodies as appropriate.

I think you will agree that this volunteer Committee has made a good start 
at looking into national bibliographical needs and problems. Further information on the various reports, studies, and activities of the Committee on Bibliographical Services for Canada may be obtained from the Committee's Secretary, Mr. Peter E. Greig, at the National Library."

It was moved by Mr. Morley, seconded by Miss Liana Van der Bellen, that this report be adopted. Carried.

In the absence of the Chairman, Mr. Douglas G. Lochhead, the report of the Nominating Committee was read by the Secretary. It was as follows:

$\begin{array}{ll}\text { Honorary President: } & \text { Dr. Marie Tremaine } \\ \text { President: } & \text { Dr. Olga B. Bishop } \\ \text { 1st Vice-President: } & \text { Dr. David M. Hayne } \\ \text { 2nd Vice-President: } & \text { Mrs. Jennifer Forbes } \\ \text { Secretary-Treasurer: } & \text { Mrs. R.C. Jacobsen } \\ \text { Associate Secretary: } & \text { M. Jean-Rémi Brault } \\ \text { Council members, 1977-1980: } & \text { Dr. Desmond G. Neill } \\ & \text { Mr. Donald E. Wick } \\ \text { Continuing on Council: } & \text { Mr. D.G. Lochhead, Past President } \\ & \text { Miss Marion D. Cameron - to } 1979 \\ & \text { Ms. Deanna Christensen - to } 1978 \\ & \text { Miss Gwynneth Evans - to } 1979 \\ & \text { Mr. John Mappin }- \text { to } 1978 \\ & \text { Mr. H. Pearson Gundy, Chairman, } \\ & \text { Publications Committee, } \\ & \text { Acting Editor, Papers/Cahiers }\end{array}$

Respectfully submitted, Dr. John Archer, Miss Clara G. Miller and Douglas G. Lochhead, Chairman.

It was moved by Mrs. Jacobsen, seconded by Mrs. Gloria Strathern, that this report be accepted. Carried.

Mr. Peter E. Greig will continue as Indexer to the Society and Miss Elizabeth Hulse as Editor of the Bulletin.

Under Other Business, Dean Halpenny spoke on behalf of the Canada Council's Consultative Group on Scholarly Publishing. She noted that the Committee, under Terms of Reference, would be asked to make recommendations on the following:

(a) Editorial procedures generally, including critical appraisal, policies respecting manuscript revision, decisions to publish and manuscript preparation.

(b) Format and design in relation to market and costs: the relative appropriateness of alternative modes of publication - including micro-reproduction for different types of scholarly materials.

(c) Improved marketing procedures for disseminating, by publication or otherwise, the results of Canadian scholarly research.

(d) Current policies for the public support of scholarly publishing, with a view to the better utilization of existing funding capacity and resources. 
(e) Other topics relating to the effective dissemination of the results of significant Canadian scholarly research.

Dean Halpenny felt that bibliographical studies should be considered as an integral part of scholarly publishing.

Mr. Peter E. Greig then made an announcement on behalf of Dr. Helmut Kallmann, Chief of the National Library of Canada's Music Division. It was as follows:

"The annual meeting of the Canadian Association of Music Libraries, held earlier this month in Waterloo, Ontario, took the form of a panel discussion on "The State of Music Bibliography in Canada". As a result of the discussion the Canadian Association of Music Libraries and the Canadian Association of University Schools of Music have decided to establish a joint committee on music bibliography in Canada to act as a coordinating and advisory body. The aim of the committee will include the coordination of individual projects, the pooling of effort to avoid duplication, and the encouragement of accurate and consistent bibliographical style. CAUSM has already nominated two persons to serve on the committee - Dr. George Proctor (University of Western Ontario) and Dr. Elaine Kellor (Carleton University) - and CAML will appoint its representatives soon. It is intended that the committee establish liaison with both the Bibliographical Society of Canada and the Committee on the Bibliographical Services for Canada."

The President then said that she had a pleasant duty to perform and asked Mr. Bruce Peel to come forward in the conferring of honorary membership on Dr. J.B. Rudnyćkyj. Mr. Peel read the following citation:

"Dr. Jaroslav Bohdan Rudnyćkyj is a cosmopolitan scholar inasmuch as his interests have ranged widely in space, time and topic. Forty years ago he obtained his $\mathrm{Ph} . \mathrm{D}$. in onomastics at the University of Lvov. He was variously a professor in Prague, Munich, and Heidelberg prior to emigrating to Canada in 1949. At the University of Manitoba he was founder, and head until retirement, of the Department of Slavic Studies.

Dr. Rudnyćkyj's scholarly involvement in learned societies is impressive, not the least as a participant in the founding of two such societies in Canada. He was appointed to the Royal Commission on Bilingualism and Biculturalism when it was established in 1963. Master of eight languages, he has published books and articles in several of them. Author, literary critic and translator, he is also a bibliographer. He has acted as consultant to the Library of Congress on Slavic bibliography. The Bibliographical Society of Canada honours him as the compiler and editor of the two bibliographical series Slava Canadiana and Ukrainica Canadiana, the first commenced in 1950, the second in 1953. His contribution to Canadian bibliography will long be remembered.

$$
\text { Slava Profesorovi Rudnyts 'komu.,", }
$$

Dr. Rudnyćkyj said that he felt greatly honoured in receiving this honorary membership in the year of his retirement and expressed his thanks to the Society.

M. Jean-Rémi Brault then introduced our first guest speaker, Monsieur Maurice Lemire, professeur a l'Université Laval de Québec et directeur du 
Dictionnaire des Oeuvres Littéraires du Québec. Monsieur Brault spoke briefly of Monsieur Lemire's work and accomplishments.

Monsieur Lemire then addressed the meeting on Le Dictionnaire des oeuvres littéraires du Québec. (The complete text of this address will be found later on in this volume.)

Dr. Hayne expressed the thanks of the Society to Professeur Lemire for his extremely interesting address and wished him every success in his work as editor of Le Dictionnaire des oeuvres littéraires du Québec.

It was then time for the presentation of the Tremaine Medal. The President said that three such medals had been presented previously and she felt it was a great honour to present the fourth such medal to Mr. William F.E. Morley. She then gave the following biographical sketch of Mr. Morley with her citation:

"William F.E. Morley, Curator of Special Collections at Queen's University, Kingston, was awarded a B.A. with honours in English and Philosophy and a Bachelor in Library Science by the University of Toronto. Before joining the staff at Queen's University as a bibliographer, Mr. Morley spent several years as a bibliographer at the John Carter Brown Library, Brown University, Providence, Rhode Island.

Since returning to Canada in $1964 \mathrm{Mr}$. Morley has written a new introduction to numerous out-of-print works which have been published by Mika Publishing in Belleville. Included are the historical atlases for the counties in eastern Ontario, Ontarian families by Chadwick, History of Leeds and Grenville by Leavitt, Life and times of Joseph Gould by W.H. Higgins, to name just a few. He has also reviewed numerous books, contributed biographies to the Dictionary of Canadian Biography, and has contributed numerous articles to journals.

In addition to the above, Mr. Morley has been the author or joint-author of several monographs - perhaps the best known of which is the multi-volume series, Canadian local histories in 1950; a bibliography. V.1 - The Atlantic Provinces was published in 1967, V.2 - La province de Québec in collaboration with André Beaulieu was published in 1971 and V.3 on Ontario is just ready to go to the University of Toronto Press. In 1973 this Society published Mr. Morley's A bibliographical study of Major John Richardson, who is perhaps best known to most of us for Wacousta.

In addition to the above publications Bill Morley has found time to play a very active role in this Society, having been President from 1972-1974. Since 1968 he has been the Editor of Books in Review, which appears in the annual Papers/Cahiers of the Society; Editor of Canadian Notes and Queries for the same length of time and is a frequent contributor to both publications.

When the National Conference on the State of Canadian Bibliography was convened in Vancouver in May 1974, Bill Morley gave an excellent report on the state of bibliography in Ontario. One of the results of the Conference was the establishment of a Committee on Bibliographical Services for Canada. Mr. Morley was unanimously chosen by Council as the Society's representative on this important committee.

It is my pleasant duty in the absence of Marie Tremaine, who, unfortunately, could not be here tonight, to present to you, William F.E. Morley, the Tremaine 
Medal on behalf of the Bibliographical Society of Canada for an outstanding contribution to the bibliography of this great country of ours."

The President then asked Mr. Morley to come forward and receive the Medal, then to give his paper. Mr. Morley said that it was difficult to find words to express his pleasure, that he had never expected to be the recipient of this Medal. He then gave his paper on "The Confessions of a Canadian Opus Eater". (Text in full will be found later on in this volume.)

On behalf of the Society, Dr. Desmond Neill thanked Mr. Morley for his address, noting that he had achieved distinction in so many fields and now had the well-deserved honour of being awarded the Tremaine Medal.

The President adjourned the meeting at 10:00 p.m.

Monsieur Brault then invited the members and guests to partake of refreshments, kindly provided by the Bibliothèque Nationale du Québec. A pleasant social period followed.

ESTHER JACOBSEN,

Secretary-Treasurer

OLGA B. BISHOP, President 